\title{
Detection of tetracycline and streptomycin in beef tissues using Charm II, isolation of relevant resistant bacteria and control their resistance by gamma radiation
}

\author{
Eman Araby ${ }^{1 \dagger}$, Hanady G. Nada ${ }^{2 *} \mathbb{D}$, Salwa A. Abou El-Nour ${ }^{1}$ and Ali Hammad ${ }^{1}$
}

\begin{abstract}
Background: Misuse of antibiotics in veterinary medicine has the potential to generate residues in animal derived products, which could contributing to the development of an important health risk either through the exposure to antibiotic residues or the transfer of antibiotic resistance among foodborne pathogens as well. Tetracycline (TE) and eptomycin (ST) are commonly used as antibiotics in the Egyptian animal husbandry. The objective of this study, quick detection of TE and ST in fresh local beef tissue samples using radioimmunoassay Charm II technique, isolation and identification of relevant highly resistant bacterial strains. In addition to investigating the effect of gamma radiation on the susceptibility of such resistant strains to TE and ST.
\end{abstract}

Results: Tetracycline (TE) was detected in all collected samples, while ST was detected in 38.46\% (5/13) and 87.5\% (7/8) of meat and liver samples, respectively.

Fifty-one bacterial isolates were isolated from the tested samples, among them, the highest resistant isolates to TE or ST were identified as Streptococcus thoraltensis, Proteus mirabilis (2 isolates) and E. coli (3 isolates). Among them, the highest $\mathrm{D}_{10}$-values in phosphate buffer; 0.807 and 0.480 ; $\mathrm{kGy}$ were recorded with $\mathrm{S}$. thoraltensis and $\mathrm{E}$. coli no.3, respectively. Such values increased to record 0.840 and $0.549 \mathrm{kGy}$, respectively after artificial inoculation into meat, indicating increased resistance to gamma radiation. Gamma radiation at dose $3 \mathrm{kGy}$ increased the susceptibility of $\mathrm{S}$. thoraltensis up to $50 \%$ to TE and ST, while the sensitivity of E. coli no.3 reached up 56\% to both antibiotics at the same dose.

Conclusions: High prevalence of TE in all fresh collected tissue samples suggests an extensively use of TE as antimicrobial in conventional beef production as compared to ST in the Egyptian cows' husbandry. Moreover, irradiation of food from animal origin by gamma radiation could potentially provide protection against resistant strains. In spite of limited samples used in this study, our data could raise the concerns of public health professionals about a withdrawal period before animals slaughtering, and address the importance of gamma radiation to minimize the hazards of foodborne resistant bacteria.

Keywords: Antibiotic resistance, Antibiotic residues, Meat, Liver, Foodborne pathogens, Streptococcus thoraltensis, E. coli, Proteus mirabilis, $\mathrm{D}_{10}$-value

\footnotetext{
* Correspondence: hanadynada@hotmail.com; hanady.nada@eaea.org.eg

tEman Araby and Hanady G. Nada contributed equally to this work.

${ }^{2}$ Drug Radiation Research Department, National Centre for Radiation

Research and Technology (NCRRT), Egyptian Atomic Energy Authority (EAEA),

3 Ahmed El-Zomor St., P.O. Box 29, Nasr City, Cairo, Egypt

Full list of author information is available at the end of the article
}

(c) The Author(s). 2020 Open Access This article is licensed under a Creative Commons Attribution 4.0 International License, which permits use, sharing, adaptation, distribution and reproduction in any medium or format, as long as you give appropriate credit to the original author(s) and the source, provide a link to the Creative Commons licence, and indicate if changes were made. The images or other third party material in this article are included in the article's Creative Commons licence, unless indicated otherwise in a credit line to the material. If material is not included in the article's Creative Commons licence and your intended use is not permitted by statutory regulation or exceeds the permitted use, you will need to obtain permission directly from the copyright holder. To view a copy of this licence, visit http://creativecommons.org/licenses/by/4.0/. The Creative Commons Public Domain Dedication waiver (http://creativecommons.org/publicdomain/zero/1.0/) applies to the data made available in this article, unless otherwise stated in a credit line to the data. 


\section{Background}

Antibiotic resistance has become a major concern due to overuse of antibiotics, leading to difficult to treat infections in humans and animals, with increased morbidity and mortality [1,2]. Antibiotics are widely used in animal, poultry and aqua-culture husbandry for prevention and control of diseases and also as growth promoters [3]. Being cheap and effective, tetracycline (TE) and streptomycin (ST) are widely used in veterinary medicine to treat infections, enhance animal growth and promote social development [4-7]. Both are blocking bacterial protein synthesis through the inhibition of $30 \mathrm{~S}$ ribosomal subunit, leading to bacterial death [4]. The inappropriate use of such antibiotics in animal production had led to their accumulation, at levels exceeding the relative maximum residue levels (MRLs), within animal tissues such as muscles, heart, liver, kidney [8, 9]. Such high levels of antibiotic residues could exert an extreme pressure that might select for resistant pathogenic strains within human tissues upon the consumption of animal-derived food products [4, 9], posing risk to human health and livestock. Accordingly, proper detection of these antibiotic residues in food intended for human consumption is very crucial for human safety [10]. Different methods are commonly used for that purpose; e.g. physio-chemical analysis (e.g GC, HPLC, LC/MS), immunological methods (e.g ELISA), and microbiological methods (e.g. growth inhibition test) [11]. Although sophisticated methods may fulfil suitability performance criteria such as method sensitivity, they need multipletime consuming steps for extraction, clean-up or preconcentration prior to measurement, as well as they are costly and laborious [12]. Accordingly, it is necessary to use a simple and rapid method for detection of antibiotic residues in food products. Charm II test is a rapid, robust and reliable isotopic assay with a multi-analytic receptor assay system, developed for the detection of variable compounds in food products, such as antibiotics, organophosphate, aflatoxin and carbamate pesticides in no more than $20 \mathrm{~min}$ [13]. It involves the use of ${ }^{3} \mathrm{H}$ or ${ }^{14} \mathrm{C}$ labelled radiotracers that compete for the binding sites (receptor sites) along with liquid scintillation counter $[11,13]$, where the amount of radiotracer bound to the receptor sites is counted per $1 \mathrm{~min}$ (cpm) in Charm II scintillation counter and compared to a previously determined control point (cp).

Ionizing radiation (gamma ray, $\mathrm{X}$-ray and electron beam) has long been recognized as a method for inhibiting food spoilage and pathogenic microorganisms in order to ensure its safety and extend shelf-life [14]. Ionizing radiation can inactivate microorganisms through direct photons energy hit on the main target (DNA) or indirectly through the production of highly reactive oxygen and hydroxyl radicals through splitting of water molecules within the product and the resident bacteria [15], leading to disruption of microbial cell membranes, protein structures, and nucleic acids. In addition, gamma radiation can enhance the susceptibilities of foodborne pathogenic bacteria to antibiotics [16]. This study aims at employing Charm II system for rapid detection of tetracycline and streptomycin in fresh local beef tissue (meat and liver) samples, isolating and identifying the relevant highly antibiotic resistant bacteria, with attempt to increase their sensitivity to those antibiotics using gamma radiation.

\section{Results \\ Detection of tetracycline and streptomycin residues by Charm II}

The sensitivity of Charm II (TE) test is set to detect as low as $25 \mathrm{PPb}(25 \mathrm{ng} / \mathrm{g})$ in muscle tissues, meeting U.S. safe tolerance or EU and Codex maximum residues limits (MRLs) (Operators Manual Charm II tetracycline test for tissue). Tetracycline-residue was detected in all the beef muscle (meat) and liver samples according to the criteria of the Charm II test established for the zero control samples (Table 1). On the other hand, streptomycin was found in 5 out of the $13(38.46 \%)$ meat samples, while 7 out of the 8 liver samples (87.5\%) were found positive for streptomycin (i.e. streptomycin residues exceeded the U.S., EU tolerance limits, in addition to the Codex (MRLs), which all fall within the range of $74-81 \%$.

Aerobic bacterial counts and coliform bacteria were determined in all beef meat and liver samples. A high count was recorded in both, meat and liver samples, with an average log count of 6.18 and $5.64 \mathrm{cfu} / \mathrm{g}$, respectively (Table 2). In meat samples, the highest log count $(6.74 \mathrm{cfu} / \mathrm{g})$ was observed with sample no.7, while the lowest log count $(5.74 \mathrm{cfu} / \mathrm{g})$ was recorded for sample no.10. On the other hand, the mean counts of coliforms were found to be 3.46 and $3.02 \mathrm{log} \mathrm{cfu} / \mathrm{g}$ in beef muscle (meat) and liver samples, respectively (Table 2).

\section{Antibiotic susceptibility testing}

Each sample (13 beef muscle (meat) and 8 beef liver) was plated on AC and EC Charm Peel Plates. A total number of 51 bacterial isolates (32 from meat and 19 from liver samples) with different morphological characteristics were isolated and tested for their susceptibility to TE and ST (Table 3), the resistance levels are very high among the isolates. Out of the 32 isolates collected from meat samples, 26 and 16 isolates (81.25 and 50\%) were resistant to (TE) and (ST), respectively. However, 5 (15\%) and 16 (50\%) were found sensitive. Out of the nineteen isolates from liver samples, 12 (63.15\%) and 15 (78.9) isolates were resistant to TE and ST, respectively against 36.8 and $21.05 \%$ were sensitive. 
Table 1 Detection of tetracycline (TE) and streptomycin (ST) residues in 13 beef muscle (meat) and 8 beef liver samples using Charm II technique

\begin{tabular}{llllll}
\hline Beef muscle (meat) & \multicolumn{5}{l}{ Beef liver } \\
\hline Sample no. & $\begin{array}{l}\text { TE } \\
\text { (cpm) }\end{array}$ & $\begin{array}{l}\text { ST } \\
\text { (cpm) }\end{array}$ & Sample no. & $\begin{array}{l}\text { TE } \\
\text { (cpm) }\end{array}$ & $\begin{array}{l}\text { ST } \\
\text { (cpm) }\end{array}$ \\
$\mathbf{1}$ & $515^{\mathrm{a}}$ & $1052^{\mathrm{a}}$ & $\mathbf{1}$ & $379^{\mathrm{a}}$ & $519^{\mathrm{a}}$ \\
$\mathbf{2}$ & $797^{\mathrm{a}}$ & 1674 & $\mathbf{2}$ & $378^{\mathrm{a}}$ & $1079^{\mathrm{a}}$ \\
$\mathbf{3}$ & $667^{\mathrm{a}}$ & $1088^{\mathrm{a}}$ & $\mathbf{3}$ & $847^{\mathrm{a}}$ & $1117^{\mathrm{a}}$ \\
$\mathbf{4}$ & $687^{\mathrm{a}}$ & 1333 & $\mathbf{4}$ & $828^{\mathrm{a}}$ & $932^{\mathrm{a}}$ \\
$\mathbf{5}$ & $924^{\mathrm{a}}$ & 1655 & $\mathbf{5}$ & $787^{\mathrm{a}}$ & $1073^{\mathrm{a}}$ \\
$\mathbf{6}$ & $804^{\mathrm{a}}$ & 1319 & $\mathbf{6}$ & $880^{\mathrm{a}}$ & $1129^{\mathrm{a}}$ \\
$\mathbf{7}$ & $977^{\mathrm{a}}$ & $1063^{\mathrm{a}}$ & $\mathbf{7}$ & $623^{\mathrm{a}}$ & $972^{\mathrm{a}}$ \\
$\mathbf{8}$ & $1113^{\mathrm{a}}$ & $1154^{\mathrm{a}}$ & $\mathbf{8}$ & $897^{\mathrm{a}}$ & 1470 \\
$\mathbf{9}$ & $1235^{\mathrm{a}}$ & 1408 & & & \\
\hline
\end{tabular}

cpm Count per minute

$\boldsymbol{c p}$ Control point (average of 6 standard readings); $\boldsymbol{c p}$ for tetracycline $=1530$ $\mathrm{cpm}$, and $\mathbf{c p}$ for streptomycin $=1290 \mathrm{cpm}$

a Positive samples, i.e. their $\mathrm{cpm} \leq$ the $\mathrm{cp}$

Generally, most isolates showed resistance to both antibiotics (TE and ST), especially those picked from EC Charm Peel Plates, where the percentage of TE and STresistant coliforms (grew on EC peel plates) were higher than the aerobic to facultative aerobic bacterial isolates (grew on AC peel plates) in both beef samples.

\section{Minimum inhibitory concentration (MIC)}

The results represented in (Table 4) show that among tetracycline-resistant isolates, 25 isolates (15 from meat and 10 from liver) recorded MICs range of $1.56-50 \mu \mathrm{g} /$ $\mathrm{ml}$, while 8 isolates (7 from meat and one from liver) recorded MICs range of $100-500 \mu \mathrm{g} / \mathrm{ml}$. Except one aerobic isolate from liver, all streptomycin-resistant isolates exhibited MICs ranging from 1.56 to $50 \mu \mathrm{g} / \mathrm{ml}$. Only six bacterial isolates [four isolates from beef muscle (meat) samples (1 from AC and three from EC peel plates)] and two isolates from beef liver samples (1 from each AC and EC peel plates) showed an MIC range as high as 600 to $1000 \mu \mathrm{g} / \mathrm{ml}$ with either TE or ST (Table 4), these six highly resistant isolates were selected for further investigations.

\section{Identification of the selected isolates}

VITEK 2 System Version 0801 (bioMèriux-Inc., Hazelwood, Mo.) was used for identifying the highly resistant 6 bacterial isolates, which showed the highest MIC values $(600-1000 \mu \mathrm{g} / \mathrm{ml})$ for either TE or ST. One isolate of Streptococcus thoraltensis, three isolates of E. coli (isolates no. 2, 3 and 4), and other two isolates were Proteus mirabilis (isolates no 5, and 6).

\section{Effect of different doses of gamma radiation on the six selected strains ( $D_{10}$-values) in sterile phosphate buffer} The radiation dose-response curves of the 6 strains in sterile phosphate buffer ( $\mathrm{pH}$ 7.2) was constructed to get their $\mathrm{D}_{10}$-values by plotting the log number of survivors counts against radiation doses. Our previous results (data not shown) indicated that the calculated $D_{10}$-value $0.807 \mathrm{kGy}$ of $S$. thoraltensis (Gram-positive strain) was the highest value among all. While, $\mathrm{D}_{10}$-values of $E$. coli

Table 2 Log aerobic and coliforms counts within beef muscle (meat) and beef liver samples

\begin{tabular}{|c|c|c|c|c|c|}
\hline \multicolumn{3}{|c|}{ Beef muscle (meat) } & \multicolumn{3}{|l|}{ Beef liver } \\
\hline Sample no. & $\begin{array}{l}\text { AerobicCount } \\
\text { Log (cfu/ml) }\end{array}$ & $\begin{array}{l}\text { ColiformsCount } \\
\text { Log (cfu/ml) }\end{array}$ & Sample no. & $\begin{array}{l}\text { AerobicCount } \\
\text { Log (cfu/ml) }\end{array}$ & $\begin{array}{l}\text { ColiformsCount } \\
\text { Log (cfu/ml) }\end{array}$ \\
\hline 1 & 5.95 & 3.7 & 1 & 4.9 & 2.44 \\
\hline 2 & 5.85 & 3.75 & 2 & $4.17^{b}$ & $2.11^{\mathrm{b}}$ \\
\hline 3 & 6.08 & 3.3 & 3 & 5.97 & 2.97 \\
\hline 4 & 6.08 & 3.77 & 4 & 6.47 & 3.2 \\
\hline 5 & 6.11 & 3.08 & 5 & 5.69 & 3.3 \\
\hline 6 & 5.97 & $3.95^{\mathrm{a}}$ & 6 & 5.47 & 3.11 \\
\hline 7 & $6.74^{\mathrm{a}}$ & 3.22 & 7 & 5.75 & 3.28 \\
\hline 8 & 5.95 & 3.39 & 8 & $6.69^{\mathrm{a}}$ & $3.77^{\mathrm{a}}$ \\
\hline 9 & 6.46 & 3.23 & & & \\
\hline 10 & $5.74^{b}$ & 3.6 & & & \\
\hline 11 & 6.39 & $3.2^{\mathrm{b}}$ & & & \\
\hline 12 & 6.64 & 3.47 & & & \\
\hline 13 & 6.54 & 3.34 & & & \\
\hline Average & 6.18 & 3.46 & & 5.64 & 3.02 \\
\hline
\end{tabular}

\footnotetext{
${ }^{a}$ Maximum Log count, ${ }^{b}$ Minimum Log count
} 
Table 3 Susceptibility profile of 51 isolated bacteria from beef muscle (meat) and beef liver against tetracycline (TE) and streptomycin (ST) antibiotics

\begin{tabular}{|c|c|c|c|c|c|c|c|c|c|c|c|c|}
\hline \multirow[t]{3}{*}{ Antibiotics } & \multicolumn{6}{|c|}{$\begin{array}{l}\text { Beef muscle-meat } \\
\text { (total 32) }\end{array}$} & \multicolumn{6}{|c|}{$\begin{array}{l}\text { Beef liver } \\
\text { (total 19) }\end{array}$} \\
\hline & \multicolumn{3}{|c|}{ AC (13) } & \multicolumn{3}{|c|}{ EC (19) } & \multicolumn{3}{|c|}{$A C(9)$} & \multicolumn{3}{|c|}{ EC (10) } \\
\hline & $\mathrm{R}$ & 1 & $S$ & $\mathrm{R}$ & 1 & $S$ & $\mathrm{R}$ & 1 & $S$ & $R$ & 1 & $S$ \\
\hline TE & 9 & 0 & 4 & 17 & 1 & 1 & 4 & 0 & 5 & 8 & 0 & 2 \\
\hline ST & 5 & 0 & 8 & 11 & 0 & 8 & 7 & 0 & 2 & 8 & 0 & 2 \\
\hline
\end{tabular}

AC Aerobic count Charm Peel Plates

EC E. coli (coliforms) count Charm Peel Plates

()$=$ Total number of isolates on each peel plates AC or EC separately picked up according to similarities in their morphological characters. Then, purified on LB agar

$R$ Resistant, I Intermediate resistant and S Sensitive

(isolates no. 2, 3 and 4) were $0.451,0.480$ and $0.476 \mathrm{kGy}$, respectively. Meanwhile, $\mathrm{D}_{10}$-values of Proteus mirablilis isolates no. 5 and 6 were 0.440 and $0.430 \mathrm{kGy}$, respectively. It is clear that, In Gram-negative strains, E. coli no.3 showed the highest $\mathrm{D}_{10}$-value, while $P$. mirabilis isolates no. 5 and 6 showed the lowest $\mathrm{D}_{10}$-values.

\section{Effect of radiation doses on bacterial susceptibility to antibiotics}

A significant dose-dependent enhancement in bacterial susceptibility to (TE) and (ST) was observed after exposure to different doses of gamma radiation, as compared to un-irradiated one. All strains showed increase in their susceptibility to TE with nearly ratios, whereas $S$. thoraltensis showed the highest susceptibility pattern after irradiation, followed by E. coli, and finally, P. mirabilis towards ST (Fig. $1 \mathrm{a}$ and b).

Effect of gamma irradiation on S. thoraltensis and E. coli no. 3 inoculated in sterile meat and their susceptibility to tested antibiotics

For the real application in the field of food irradiation, $S$. thoraltensis and $E$. coli no. 3 were artificially inoculated in pre-radiated sterilized beef muscle (meat). The

Table 4 Minimum inhibitory concentrations (MICs) for all resistant isolates

\begin{tabular}{|c|c|c|c|c|c|c|c|c|}
\hline \multirow{3}{*}{$\begin{array}{l}\text { Antibiotic } \\
\text { concentrations } \\
\mu \mathrm{g} / \mathrm{ml}\end{array}$} & \multicolumn{4}{|c|}{ Beef muscles (meat) } & \multicolumn{4}{|c|}{ Beef liver } \\
\hline & \multicolumn{2}{|l|}{$\overline{\mathrm{TE}}$} & \multirow{2}{*}{$\begin{array}{l}\text { ST } \\
\text { AC (5) }\end{array}$} & \multirow[b]{2}{*}{ EC (11) } & \multicolumn{2}{|l|}{$\overline{\mathrm{TE}}$} & \multicolumn{2}{|l|}{ ST } \\
\hline & $\begin{array}{l}A C \\
\text { (9) }\end{array}$ & EC (17) & & & $\begin{array}{l}A C \\
\text { (4) }\end{array}$ & $\begin{array}{l}\mathrm{EC} \\
\text { (8) }\end{array}$ & $\begin{array}{l}A C \\
\text { (7) }\end{array}$ & $\begin{array}{l}\text { EC } \\
\text { (8) }\end{array}$ \\
\hline $1.56-50$ & 8 & 7 & 5 & 11 & 3 & 7 & 6 & 8 \\
\hline $100-500$ & 0 & 7 & 0 & 0 & 0 & 1 & 0 & 0 \\
\hline $600-1000$ & 1 & 3 & 0 & 0 & 1 & 0 & 1 & 0 \\
\hline
\end{tabular}

() = Total number of isolates

AC Aerobic count Charm Peel Plates for aerobic bacteria

EC E.coli count Charm Peel Plates for coliform bacteria

Shaded isolates were chosen for further investigations calculated $\mathrm{D}_{10}$-values were 0.840 and $0.549 \mathrm{kGy}$ for $S$. thoraltensis and E. coli no. 3, respectively, as shown in Fig. 2. The results of this study also indicated that the $\mathrm{D}_{10}$-values of the two selected strains were higher in beef muscle (meat) in comparison with their $\mathrm{D}_{10}$-values in buffer phosphate solution.

Figure $3(\mathrm{a}$ and $\mathrm{b}$ ) shows that the sensitivity of $S$. thoraltensis and $E$. coli no.3, inoculated into the beef muscle (meat) samples, to TE and ST increased as the radiation dose increased, as compared to the un-irradiated one (control). Where, the sensitivity of $S$. thoraltensis to TE increased up to $50 \%$ at doses $3 \& 3.5 \mathrm{kGy}$ and up to $60 \%$ at $4.5 \mathrm{kGy}$. While the sensitivity rate to ST was increased up to 52 and $55 \%$ at 4.0 and $4.5 \mathrm{kGy}$, respectively. No significant change $(P$-value $\geq 0.05)$ in the sensitivity of E.coli no.3 to TE and ST was observed till $1.5 \mathrm{kGy}$. While, radiation doses in the range of $2.0-4.5 \mathrm{kGy}$ increased the sensitivity of E.coli no. 3 to TE by 45 to $67.6 \%$ and to ST by 45.4 to $62.5 \%$, respectively

Generally, as irradiation dose increased, the sensitivity to both antibiotics increased. At high radiation doses, 3 , 3.5, 4 and $4.5 \mathrm{kGy}$, the sensitivity of E.coli no.3 to both tested antibiotics was slightly higher than $S$. thoraltensis.

\section{Discussion}

The excessive use of antibiotics in livestock, has a potential to generate residues in animal derived products. The consumption of such products could result in serious side effects on consumers, such as emergence of bacterial resistant strains, gastrointestinal disorders, toxicity and allergic reactions [4].

Charm II system, is widely used as a rapid, robust and reliable radioreceptor assay for the detection of different veterinary antibiotics as tetracycline and streptomycin, in milk, meat, sea food, and honey. This method is used to determine the concentration of antibiotic residues in the sample comparative (either +ve or $-\mathrm{ve}$ ) to a control point (cp), which is often selected to be an adjusting guideline value [17].

Using Charm II system, tetracycline residues were detected in $100 \%$ beef meat and liver samples which is higher than the previous reported [18], this wide variation could be due to difference in countries, host, or food from where the microorganisms have been isolated.

It has been reported [5] that the ingested TE was widely distributed all over the body tissues, including bones and teeth. The overwhelmed presence of $\mathrm{TE}$ above MRLs in all tested samples may result from the routine addition of TE to drinking water of the livestock by farmers and meat producers for economic reasons. This practice boosts the absorbance of TE in animal body and leads to accumulation of TE in animal muscles and tissues [19]. Moreover, our result reveals the absence of antibiotic withdrawal period before animals 

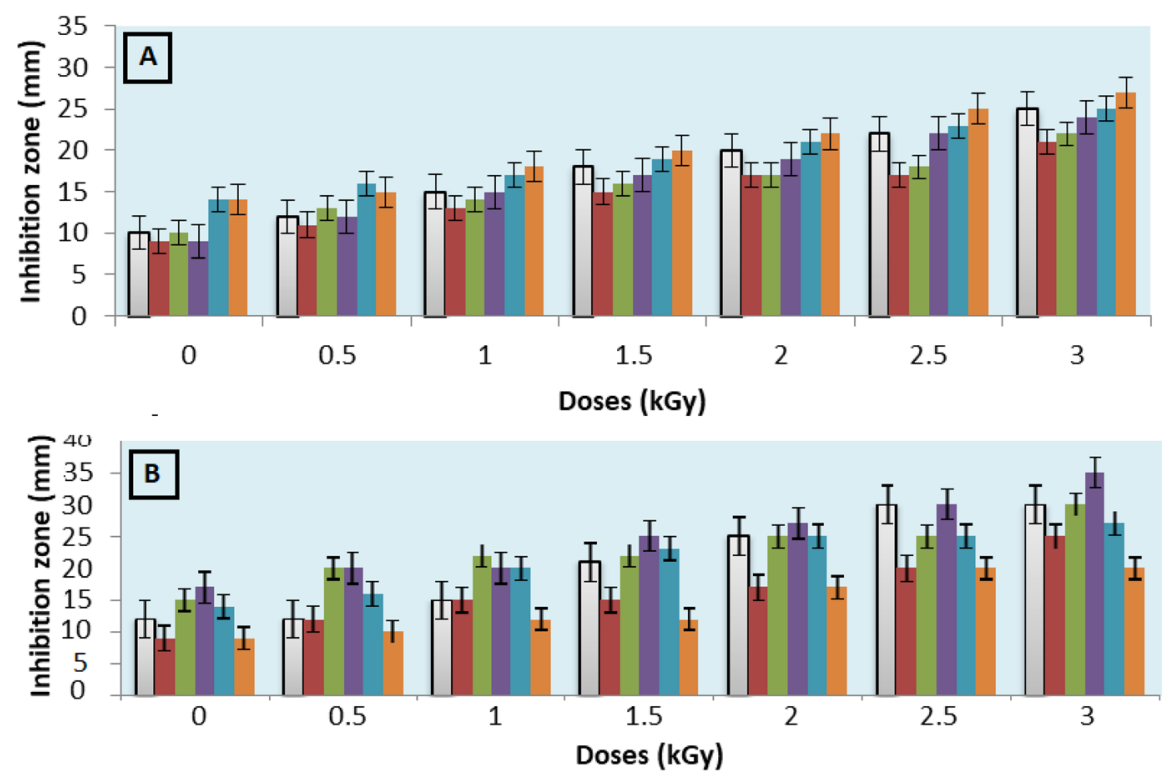

$\square$ S.thoraltensis $\square$ E.coli no. $2 \square$ E.coli no.3 E.coli no. $4 \square$ P. mirabilis no.5 $\square$ P. mirabilis no. 6

Fig. 1 Effect of different gamma radiation doses on the susceptibility of the six selected strains to (a) tetracycline and (b) streptomycin

slaughtering, especially TE has a short half-life $(7-10 \mathrm{~h})$, where $60 \%$ of TE is excreted in urine [5]. This result rises a big concern on the illegal practices of animal producers and the absence of monitoring from authorities before slaughtering animals and marketing.

We recorded a higher ST residues within liver samples $(87.5 \%)$ than in meat samples $(38.46 \%)$ coming from different sources. Similar results have been reported $[5,20$, 21 ], they found that elevated percentages of antibiotic residues accumulation in beef, chicken and pork liver than in other tested tissues, which incorporate the findings of this research. This indicated that, most of the toxic materials and residues are metabolized and detoxified in the liver [21]. This explains the high prevalence of both antibiotics (TE and ST) in our fresh liver samples.

Unintentional consumption of antibiotics in animal feeding has been linked to the increase emergence of resistant strains posing human health to serious threats [5, 22]. Enterococci demonstrates antimicrobial intrinsic resistance to a variety of antibiotics, including streptomycin and tetracycline has been reported [18]. An elevated percentage of ST-resistant pathogenic E. coli (40\%) in sheep grazed on field containing ST residues, in comparison with others grazed on field without ST residues (15\%) has also been reported [23]. Moreover, 92.6\% of $E$. coli exhibited resistance to ST as well as resistance to other antibiotics (tetracycline, ampicillin, sulfamethoxazole and chloramphenicol), which in line with our

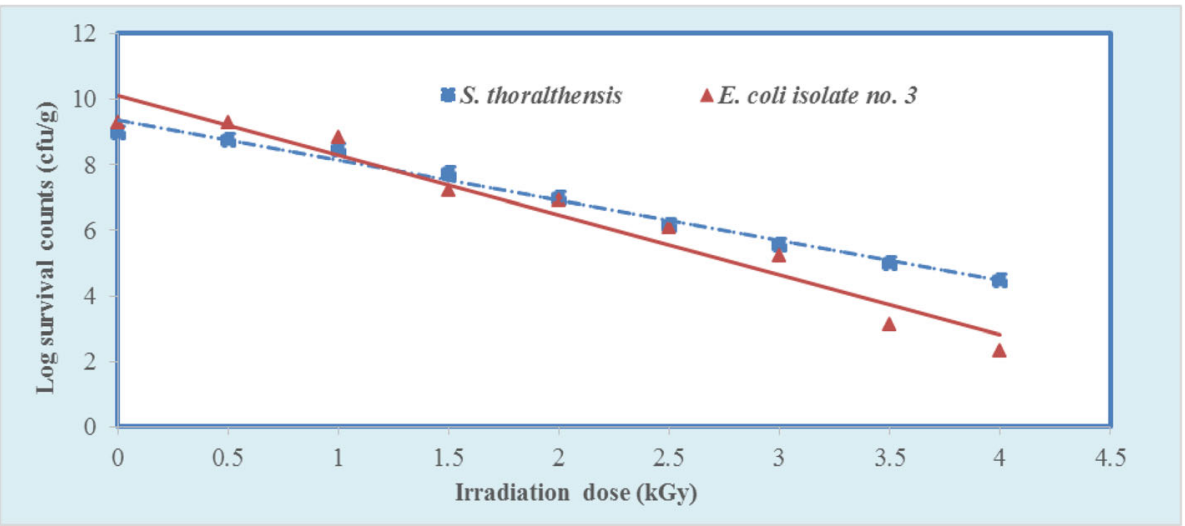

Fig. 2 Dose-response curve of S. thoraltensis and E. coli no. 3 in beef muscle (meat) 

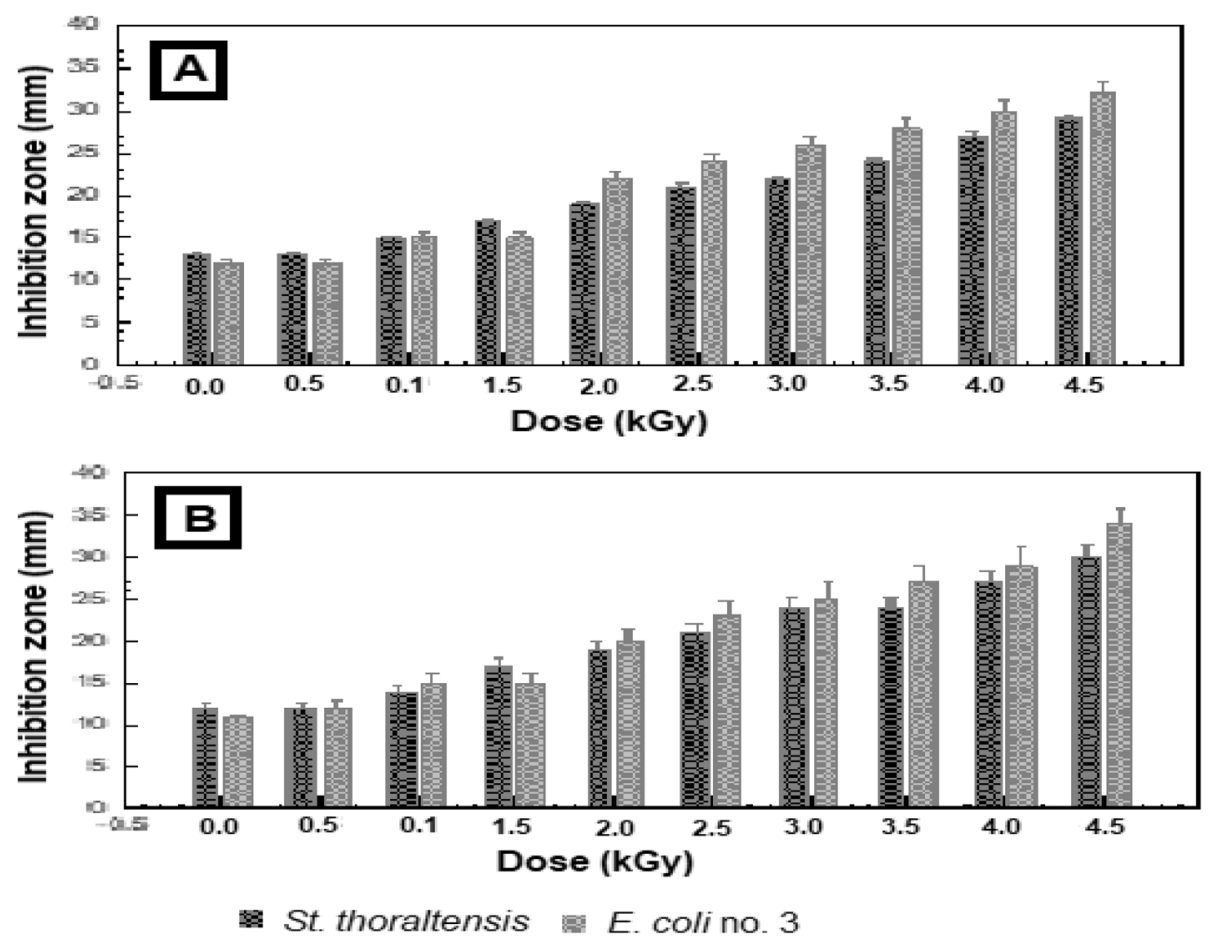

Fig. 3 Effect of different gamma radiation doses on the susceptibility of $S$. thoraltensis and E. coli no.3, artificially inoculated into meat samples, to (a) tetracycline and (b) streptomycin

results, where most of our isolates showed resistance to both tested antibiotics, especially those picked from (EC) coliform Charm Peel Plates. This is a disastrous situation, leading to the emergence of multi-drug resistant pathogenic isolates; multi-drug resistant isolates rapidly acquire resistance to two or more antimicrobial agents traditionally used for treatment [24].

It is well known that fresh meat possesses high counts of microbial contaminants originating from different sources during the slaughtering. It was found that [25] the aerobic bacterial counts were higher than others in raw meat and uncooked meat products, its mean value ranges from less than $10^{5}$ to more than $10^{7} \mathrm{cfu} / \mathrm{ml}$ which in accordance with our result.

High presence of coliform bacteria in this research indicated the possible presence of pathogenic bacteria particularly enteropathogenic $E$. coli. It is well known that certain strains of $E$. coli cause diseases in humans, thus $E$. coli regarded as a potential pathogen. Despite of the improved efforts to ensure the distribution of hygienic meat products, meat products harbouring pathogenic bacteria have increased [26]. In contrast to the results of the current study, low coliform counts in beef cattle $\left(5.29 \times 10^{1} \mathrm{cfu} / \mathrm{g}\right)$ was found [27]. However, higher contamination rates within Korean cold duck meats with total aerobic bacterial count of 4-7 $\log \mathrm{cfu} / \mathrm{g}$ and coliforms count of 3.72-5.92 cfu/g has been reported [28].
In the present study, the highest six resistant bacteria isolates to TE and ST were identified to be Streptococcus thoraltensis (one isolate), E. coli (three isolates) and Proteus mirabilis (two isolates). Streptococcus thoraltensis, as a new species is described in 1997 [29]. It is Grampositive bacterium inhabitant within the intestinal tract of swine and rabbit feces [30, 31]. S. thoraltensis has been isolated from water pipe components (water pool) [32]. To the best of our knowledge, S. thoraltensis has not been previously isolated from meat. Very little is known about the pathogenic potential of such bacterium to humans. However, The first chorioamnionitis of human infection by $S$. thoraltensis has recently been described in 2015 [33]. S. thoraltensis showed a high resistance to tetracycline which appear to be directly related to the industry, antimicrobial usage and resistance selection [31].

Escherichia coli, as one of Gram-negative coliform bacteria, has become one of the microorganisms commonly resistant to antimicrobials [34]. The emergence of antimicrobial resistance among E. coli has increasingly important from the view point of public health [35]. E. coli is frequently more resistant to tetracycline, streptomycin, ampicillin, sulfamethoxazole, chloramphenicol and gentamycin, compared with other agents [34, 36]. Resistance profile of the $E$. coli isolates differed significantly by the type of animal (source of isolation) and type of routinely sub-therapeutic levels of antibiotics those animals were fed on. 
Proteus mirabilis is a member of enterobacteriaceae family of Gram-negative bacteria. It has been isolated from different food including fresh meat and uncooked meat products $[37,38]$. It can cause food poisoning when consumed in contaminated food such as meat, vegetables and seafood [39]. Data on the susceptibility of $P$. mirabilis indicate a high risk.

Several investigators [40-42] reported that the $D_{10^{-}}$ values of Gram-positive bacteria were more resistant to ionizing radiation than Gram-negative bacteria, vegetative cocci were more resistant than vegetative bacilli and bacterial spores were more resistant than vegetative bacilli. To our knowledge, the $\mathrm{D}_{10}$-value of $S$. thoraltensishas wasn't previously determined, however the $\mathrm{D}_{10^{-}}$ values of other streptococci species causing human infection have been determined. For example, the $D_{10^{-}}$ value of Streptococcus faecalis was determined to be in the range of 0.65 to $1.1 \mathrm{kGy}$ [42]. Our results revealed small variations in the radiation resistance among $E$. coli (isolates no. 2, 3 and 4) also between Proteus mirablilis isolates no. 5 and 6 , this might be due to the variation in the animal source. It has been reported that the $\mathrm{D}_{10^{-}}$ values of $E$. coli including $E$. coli $\mathrm{O} 157: \mathrm{H} 7$ ranged from 0.12 to $0.39 \mathrm{kGy}$ depending on the source of isolation, strains, temperature during irradiation, suspending media, presence or absence of oxygen, etc. In addition, radiation resistance become higher in freezing temperatures and differs with species in the same genera and even with strains of the same species, although the variation among strains of the same species is very small so that it could be negligible in the applications [40, 43]. The $\mathrm{D}_{10}$-values of $P$. mirabilis ranged from 0.24 to 0.5 kGy [44]. This indicates that the $\mathrm{D}_{10}$-values of $P$. mirablis strains in our research fell in this reported range. As, $P$. mirablis is a Gram-negative bacterium its $D_{10^{-}}$ values were nearly as $E$. coli.

In the present study, the increasing in the susceptibility of the isolates to TE and ST by gamma irradiation is dose depending manner and could be explained by the nature, the penetration mode inside the cells, or by the action way of the antibiotics [45]. E. coli and P. mirabilis tested strains (as Gram-negative bacteria) were more resistant to the tested antibiotics than S. thoraltensis (as Gram-positive bacteria) which is in accordance with the preview reported [46]. This could explained by the outer the outer membrane surrounding the cytoplasm membrane in Gram-negative bacteria, acts as a barrier that excluding certain antibiotics from penetrating the bacterial cell, and plays an important role in the definition of intrinsic resistance in Gram-negative bacteria. Additionally, the number of efflux pump porins and outer membrane proteins play major roles in the resistance of Gram-negative bacteria to antibiotics [47].
The results obtained from this study were in agreement with other previous reports [46], who found that gamma radiation $(0.5,1.5$, and $2 \mathrm{kGy})$ increased Staphylococcus aureus and Pseudomonas aeruginosa inhibition zone against gentamycin. A significant increase in sensitivity of the four Salmonella isolates to different antibiotics after irradiation at $1.0 \mathrm{kGy}$ has been shown [45]. A highly significant dose effect was observed at $2 \mathrm{kGy}$ for all or some of the tested antibiotics depending on the isolates. It was found [16] that gamma radiation emitted from the hot soil of the high background radiation areas was capable of making significant alterations in the pathogen bacterial susceptibility to antibiotics that differ with different bacterial isolates. Others $[45,48]$ reported that radiation induced reactive oxygen species upon water radiolysis affecting the membrane permeability of ionic channels in the bacterial cell membrane. It may also be possible that gamma radiation induces an effect on the active transport mechanism in the bacterial cell membrane playing a role in efflux pump proteins, which is one of the mechanisms by which bacteria develop resistance to antibiotics. It is well known that at higher water content, microorganism is more sensitive to ionizing radiation because of higher presence of oxidizing free radicals formed from water radiolysis upon irradiation. In a complex food system, some chemical components, such as proteins in meat act as protective agents or scavengers of the formed free radicals [49]. This may explain the higher $D_{10}$-values of $S$. thoraltensis and E. coli no. 3 inoculated in meat than in phosphate buffer in this study.

\section{Conclusions}

Although, the limitation of fresh local beef tissue samples, this study revealed unexpected predominant presence of TE residues and high levels of ST residues above the MRLs by using Charm II screening test. That should increase necessity to control the use of TE and/or ST antibiotics in animal feedings and imposing an enough withdrawal period before slaughtering the animals by farmers and animal producers. In addition, needs to monitor the antibiotic residues before marketing by authorized organizations. Six isolates were exhibited highest resistance level to both TE and ST, this study was able to overcome TE and ST-resistant by gamma radiations. The overall results suggest that gamma irradiation within (3.0-4.5 kGy) range could improve the meat safety, quality by increasing the sensitivity of the survival foodborne pathogenic bacteria to antibiotics which leads to enhancing public health. 


\section{Methods}

\section{Sampling}

A total of 21 samples of different fresh beef tissues (13 beef muscle (meat) and 8 beef liver) were purchased directly from different butchery shops in Cairo city. Samples were packaged in sterile polyethylene bags and transferred within $1-2 \mathrm{~h}$ in a cold box at $4{ }^{\circ} \mathrm{C}$ to the laboratory, where they analysed directly.

\section{Detection of antibiotic residues using Charm II}

Charm II 7600 Analyser (Charm Science Inc. 659 Andover St., Lawrence, MA, USA) was used for detection of TE and ST in the beef samples according to the method [50]. Radioimmunoassay Charm II system is a rapid, precise, reliable and simple multi-analyze receptor assay used for screening of different antibiotic residues in milk and food of animal origin. This system offering a new, simple, cheap and sensitive approach in local laboratories. Following the manufacturer instructions, a specific amount of the radiotracer was added to a binding reagent with specific receptor sites that bind the drug in the sample extraction medium, the amount of tracer that binds to the receptor sites was counted per minute (cpm) with Charm II scintillation counter and compared to a previously determined control point (cp) (average of 6 standard readings). Any antibiotic residue in the sample competes with the tracer for receptor sites in the binding agent. Negative control (sample without antibiotic residues) had (cpm) value greater than (cp). While the positive sample with antibiotic residues were showed (cpm) value less than (cp).

\section{Enumeration \& isolation of bacteria using Charm Peel plates}

Bacterial isolates were enumerated using Charm Peel Plate (Charm Sciences Inc., Lawrence, MA, USA), using aerobic count $(\mathrm{AC})$ plates (kit code: $\mathrm{PP}-\mathrm{AC}-100 \mathrm{k}$ ) to detect aerobic isolates. While, E. coli count (EC) plates (kit code: PP-EC-100 k) to detect the coliform isolates. This test has been certificated by the Association of Analytical Communities (AOAC) research Institute as a performance tested method 071501 [51]. Briefly, $25 \mathrm{~g}$ of ground meat or liver were homogenized for 2 min with $225 \mathrm{ml}$ of peptone saline solution $(0.1 \%$ peptone and $0.85 \%$ $\mathrm{NaCl}$ ), samples were then 10 -fold serially diluted, $1 \mathrm{ml}$ sample dilutions $\left(10^{-4}-10^{-7}\right)$ were added to distinct Charm Peel Plates and incubated at $35 \pm 1{ }^{\circ} \mathrm{C}$ for $18-24$ h. Pink or blue/ violet colonies on the AC (Fig. 4 a) or EC (Fig. 4 b) plates, respectively were considered, counted and expressed as $\mathrm{cfu} / \mathrm{ml}$. The experiment was performed in triplicates. One colony from each group has the same colour and size on the same peel plate (AC or EC) was picked. Finally, each microbial isolate was separately streaked on Lauria Bertani (LB) agar (Oxoid, England) and incubated at $35 \pm 1{ }^{\circ} \mathrm{C}$ for $18-24 \mathrm{~h}$.

\section{Antibiotic susceptibility testing of the isolates}

All isolates were tested for their susceptibility to TE and ST using antibiotic discs, TE $(30 \mu \mathrm{g})$ and ST $(10 \mu \mathrm{g})$ purchased from (Oxoid, England). This test was assessed by Kirby-Bauer disc diffusion agar method according to Clinical and Laboratory Standards Institute's (CLSI) guidelines [52]. Isolates were categorized as susceptible $(\mathrm{S})$, intermediate resistant (I) or resistant (R) based on the mean of the inhibition zone diameter of three replicates.

\section{Detection of the minimum inhibitory concentrations (MICs)}

All bacterial isolates that showed resistance against TE and ST were selected to determine their MICs to both antibiotics, using the resazurin assay microtitre-plate described elsewhere [53]. A wide concentration range of sixteen concentrations $(1000,900,800,700,600,500$, $400,300,200,100,50,25,12.5,6.25,3.125$ and $1.56 \mu \mathrm{g} /$
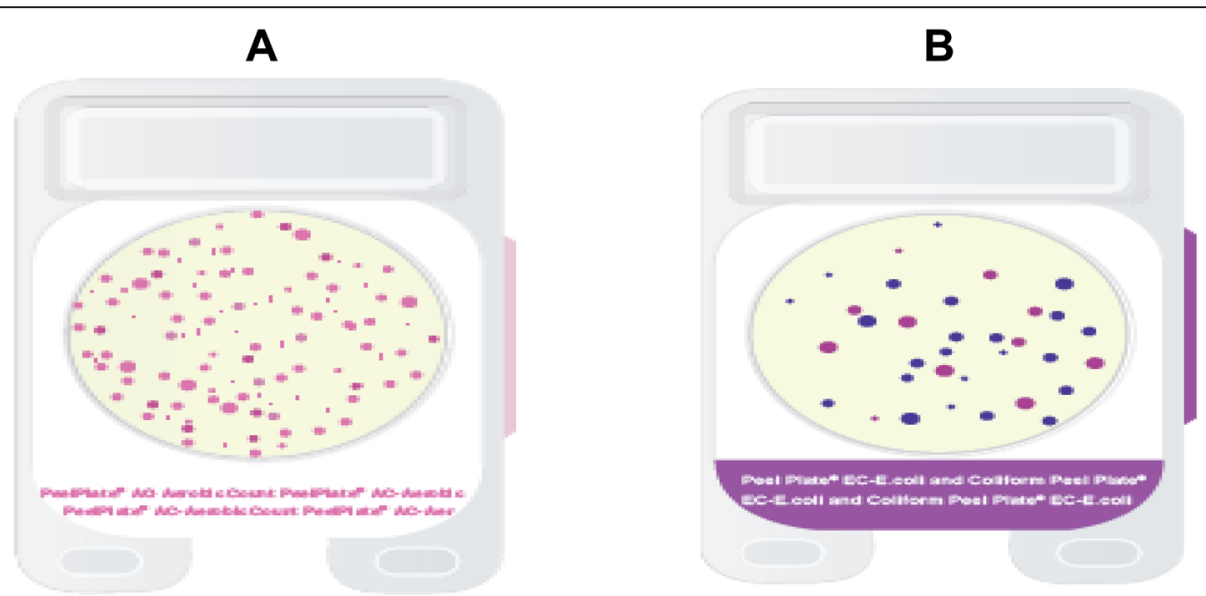

Fig. 4 Charm Peel Plates $\mathbf{a}$, for aerobic count (AC) and $\mathbf{b}$, for coliform count (EC) 
$\mathrm{ml}$ ) of each TE or ST was used separately. The MIC was defined as the lowest concentration of tested antibiotic that inhibited $90 \%$ of bacterial growth.

\section{Identification of the selected isolates}

The VITEK2 system Version 08.01 (bioMe'rieux, Inc., Hazelwood, Mo.) for microbial identification was used to identify the isolates that showed highly MICs values.

\section{Irradiation process}

The irradiation process was achieved using Cobalt 60 $\left({ }^{60} \mathrm{Co}\right)$ Gamma Cell GC 220, product of Canada Co. Ltd. located at the National Centre for Radiation Research and Technology (NCRRT), Atomic Energy Authority, Cairo, Egypt. Irradiation process was achieved at ambient temperature. The dose rate of this source was 1.538 $(\mathrm{kGy} / \mathrm{h})$ at the time of the experiment. Reference alanine dosimeters traceable to National Physical Laboratory (NPL), Uk was used to measure the minimum and maximum doses during irradiation process.

\section{Determination of radiation $D_{10}$-values}

The $\mathrm{D}_{10}$-value was used to evaluate the sensitivity of the identified bacterial strains to gamma radiation. Bacterial strains that showed highest MIC values with TE or ST were chosen to determine their $\mathrm{D}_{10}$-values in sterile phosphate buffer saline. Briefly, 5 pure colonies from each strain were inoculated into $100 \mathrm{ml}$ tryptic soya broth, incubated in shaker incubator $(150 \mathrm{rpm}$ at $35 \pm$ $\left.1{ }^{\circ} \mathrm{C}\right)$ for $18-24 \mathrm{~h}$, then centrifuged $(6000 \mathrm{rpm} / 15 \mathrm{~min}$ at $\left.4{ }^{\circ} \mathrm{C}\right)$, the supernatant was decanted and cell pellet was washed three times with sterile phosphate buffer $(\mathrm{pH}$ 7.2 ) to remove excess media. Volumes of $250 \mathrm{ml}$ of bacterial suspensions were prepared and spectrophotometrically adjusted to $10^{7}-10^{8} \mathrm{cfu} / \mathrm{ml}$, then dispensed $10 \mathrm{ml}$ into tubes, that were then subjected to different doses of gamma radiation $(0.0,0.5,1.0,1.5,2.0,2.5$, and $3.0 \mathrm{kGy})$, three tubes each. Finally, the irradiated bacterial suspensions were each 10 -fold serially diluted, dilutions of $\left(10^{-4}-10^{-8} \mathrm{ml}\right)$ were inoculated into the relevant peel plate (AC or EC), incubated at $35 \pm 1{ }^{\circ} \mathrm{C}$ for $18-24 \mathrm{~h}$ and the survival colonies were counted by colony counter (Stuart scientific co. ltd, UK).

The $\mathrm{D}_{10}$-value is the radiation dose in (kGy) required to reduce the viable count of the microbe by $90 \%$ or by 10-fold (one log cycle). The dose-response curve for each bacterial strain was constructed by plotting log survival counts against gamma radiation doses (kGy). The slope of the individual survivor-curve was calculated from a linear regression through Excel Microsoft Office Professional Plus 2013. The $\mathrm{D}_{10}$-value was calculated using the previously mentioned equation [54] as follow:

$$
\mathrm{D}_{10}=-1 / \mathrm{b}
$$

$$
\mathrm{b}=\sum \mathrm{xy}-\mathrm{n} \overline{\mathrm{x}} \overline{\mathrm{y}} / \sum \mathrm{x}^{2}-\mathrm{n} \overline{\mathrm{x}}^{2}
$$

Where:

$\mathrm{x}=$ Dose level $(\mathrm{kGy}), \mathrm{y}=\mathrm{Log}$ number of bacterial survival after receiving $\mathrm{x}$ amount of radiation, $\mathrm{n}=$ number of calculated point.

Finally, the susceptibility of irradiated tested strains to TE and ST was retested and compared to unirradiated (control), all experiments were conducted in triplicate.

\section{Effect of gamma radiation on the selected strains inoculated into meat and their susceptibility to the tested antibiotics}

Among the identified tested strains, the highest antibiotic resistant and radiation-resistant Gram-positive strain (Streptococcus thoraltensis) and Gram-negative strain (E. coli no. 3), as determined by $\mathrm{D}_{10}$-value, were selected to identify the most effective radiation dose on inoculated beef muscle (meat) only. One kilogram of previously tested meat samples was grounded and divided into equal portions of $10 \mathrm{~g}$, packed in polyethylene bags and deep frozen at $-20^{\circ} \mathrm{C}$ (to avoid the indirect effect of gamma radiation, resulting from water radiolysis (free radicals, $\mathrm{OH}^{\circ}, \mathrm{H}^{\mathrm{o}}$ and $\mathrm{e}^{-}$) that adversely affected the meat quality). Frozen samples were sterilized by gamma irradiation at a dose of $20.0 \mathrm{kGy}$. Under aseptic conditions, each portion was individually inoculated with $1 \mathrm{ml}$ cell suspension $\left(10^{7}-10^{8} \mathrm{cfu} / \mathrm{ml}\right)$ of either S. thoraltensis or E. coli no. 3. Inoculated samples were individually exposed to gamma radiation $(0.0,0.5,1.0,1.5,2.0$, $2.5,3.0,3.5,4.0$ and $4.5 \mathrm{kGy})$. After irradiation, each were 10 -fold serially diluted and the number of survivors was determined by colony counter (Stuart scientific co. ltd, UK), and the $\mathrm{D}_{10}$-values were calculated as mentioned above. Finally, the antibiotic sensitivity of the tested strains towards TE and ST was retested as previously mentioned, all tests were done in triplicate.

\section{Statistical analysis}

All experiments were carried out in three replicates; analysis of variance using one-way ANOVA, followed by Duncan's test was performed to test the significance of differences between means obtained among the treatments at the $5 \%$ level of significance. Statistical analysis was performed using SPSS version 16.0. Error bars in figures represent standard error.

\footnotetext{
Abbreviations

TE: Tetracycline; ST: Streptomycin; kGy: KiloGray (unit of absorbed dose); MICs: Minimum inhibitory concentrations; S. thoraltensis: Streptococcus thoraltensis; P. mirabilis: Proteus mirabili; E. coli: Escherichia coli; GC: Gas chromatography; HPLC: High performance liquid chromatography; LC/ MS: Liquid chromatography-mass spectrometry; ELISA: Enzyme-Linked immunosorbent assay; CP: Control point; AOAC: Association of analytical communities; NCRRT: National centre for radiation research and technology; cpm: Counted per minute; AC: Aerobic plate Count; EC: E. coli count plates;
} 
LB: Lauria bertani agar; $\mu$ g: Micro gram; g: Gram; S: Sensitive; I: Intermediate resistant; R: Resistant; VITEK2: Name of automated system for bacterial identification; MRLs: Maximum residues limits; U.S: United State; EU: Europe

\section{Acknowledgements}

The authors would like to sincerely thank Dr. Soheir A. A. Hagras, lecturer at NCRRT, for her contribution in final language editing of the manuscript.

\section{Authors' contributions}

The research plan for this study and collected samples were done by all coauthors. AH designed and supervised this study, in addition revised the manuscript. SAA provided us with Charm Peel Plates, performed the charm I analysis, analysed the $D_{10}$-values and shared in manuscript revision. EA and HGN were contributed in experimental design, prepared the samples for analysis, performed all microbiological assays, collected and identified the strains, furthermore, conducted data analysis and wrote the manuscript. All authors read and approved the final manuscript.

\section{Funding}

This research did not receive any specific fund from funding agencies in the public, commercial, or not-for-profit sectors. Financial support of this work was only provided by NCRRT, Atomic Energy Authority.

\section{Availability of data and materials}

The datasets used and/or analysed during the current study are available from the corresponding author on request.

\section{Ethics approval and consent to participate}

Not applicable

\section{Consent for publication}

Not applicable

\section{Competing interests}

The authors declare that they have no competing interests.

\section{Author details}

'Radiation Microbiology Department, National Centre for Radiation Research and Technology (NCRRT), Egyptian Atomic Energy Authority (EAEA), 3 Ahmed El-Zomor St., P.O. Box 29, Nasr City, Cairo, Egypt. ${ }^{2}$ Drug Radiation Research Department, National Centre for Radiation Research and Technology (NCRRT), Egyptian Atomic Energy Authority (EAEA), 3 Ahmed El-Zomor St., P.O. Box 29, Nasr City, Cairo, Egypt.

\section{Received: 16 October 2019 Accepted: 22 June 2020}

Published online: 29 June 2020

\section{References}

1. Grace D. Review of evidence on antimicrobial resistance and anima agriculture in developing countries. Int Livest Res Inst (ILRI). 2015; https:// assets.publishing.service.gov.uk/media/57a0897e40f0b649740000e0/EoD_ Consultancy_June15_Ag_Related_AMR.pdf.

2. Lekshmi M, Ammini P, Kumar S, Varela MF. The food production environment and the development of antimicrobial resistance in human pathogens of animal origin. Microorganisms. 2017:5:11-25.

3. Offiah NV, Adesiyun AA. Detection of antimicrobial residues in chicken muscle and liver sold at retail outlets in Trinidad. Int J Poult Sci. 2015;14: 456-62.

4. Du B, Wen F, Zhang Y, Zheng N, Li S, Li F, et al. Presence of tetracyclines, quinolones, lincomycin and streptomycin in milk. Food Control. 2019;100: $171-5$.

5. Ramatla T, Ngoma L, Adetunji M, Mwanza M. Evaluation of antibiotic residues in raw meat using different analytical methods. Antibiotics. 2017;6: 34-50.

6. Alsager OA, Alnajrani MN, Alhazzaa O. Decomposition of antibiotics by gamma irradiation: kinetics, antimicrobial activity, and real application in food matrices. Chem Eng J. 2018;338:548-56.

7. Abdelaziz Al, Tawfik AG, Rabie KA, Omran M, Hussein M, Abou-Ali A, et al. Quality of community pharmacy practice in antibiotic self-medication encounters: a simulated patient study in upper Egypt. Antibiotics. 2019;8: $35-49$.
8. Donoghue DJ. Antibiotic residues in poultry tissues and eggs: human health concerns? Poult Sci. 2003:82:618-21.

9. Nisha AA. Antibiotic residues - a global health hazard. Vet World. 2008;1: 375-7.

10. Economou V, Gousia P. Agriculture and food animals as a source of antimicrobial-resistant bacteria. Int Drug Resis. 2015:8:49-61.

11. Navrátilová P. Screening methods used for the detection of veterinary drug residues in raw cow milk-a review. Czech J Food Sci. 2008;26:393-401.

12. Mastovska K. Multiresidue analysis of antibiotics in food of animal origin using liquid chromatography-mass spectrometry. Methods Mol Biol. 2011; 747:267-307.

13. Salter R. Charm II system-comprehensive residue analysis system for honey. APIACTA. 2003:38:198-206.

14. Arvanitoyannis I. Irradiation of food commodities: techniques, applications, detection, legislation, safety and consumer opinion. 1st ed. USA: Academic Press: Elsevier Inc; 2010. https://books.google.com.eg/books?hl=en\&lr=\&id= 5sAr7nawmb8C\&oi=fnd\&pg=PP2\&dq=Arvanitoyannis+1.+Irradiation+of+ food+commodities:+techniques,+applications, +detection,+legislation,+ safety+and+consumer+opinion:+academic+press:+Elsevier++Inc\%3B+2010. \&ots=aFEadqL2Co\&sig=NLeZRq7C8F3uS_P6NY3wHYnAYVo\&redir_esc $=y \# v=$ onepage\&q=Arvanitoyannis\%201.\%20lrradiation\%20of\%20food\%2 Ocommodities\%3A\%20techniques\%2C\%20applications\%2C\%20detection\%2 C\%20legislation\%2C\%20safety\%20and\%20consumer\%20opinion\%3A\%2 Oacademic\%20press\%3A\%20Elsevier\%20\%20Inc\%3B\%202010.\&f=false.

15. Thompson JE, Blatch ER. Gamma irradiation for inactivation of C.parvum, E. coli and coliphage Ms-2. J Environ Eng. 2000;125:761-8.

16. Mortazavi SMJ, Zarei S, Taheri M, Tajbakhsh S, Mortazavi SA, Ranjbar S, et al. Sensitivity to antibiotics of bacteria exposed to gamma radiation emitted from hot soils of the high background radiation areas of Ramsar, northern Iran. Int J Occup Environ Med. 2017:8:80-4.

17. Kwon $\mathrm{SI}$, Owens G, Ok YS, Lee DB, Jeon WT, Kim JG, et al. Applicability of the charm II system for monitoring antibiotic residues in manure-based composts. Waste Manag. 2011;31:39-44.

18. Kilonzo-Nthenge A, Brown A, Nahashon SN, Long D. Occurrence and antimicrobial resistance of enterococci isolated from organic and conventional retail chicken. J Food Prot. 2015:78:760-6.

19. Al-Ghamdi M. Residues of tetracycline compounds in poultry products in the eastern province of Saudi Arabia. Public Health. 2000;114:300-4.

20. Olatoye I, Ehinmowo A. Oxytetracycline residues in edible tissues of cattle slaughtered in Akure, Nigeria. Niger Vet J. 2011;31:93-102.

21. Mesgari Abasi M, Rashidi MR, Javadi A, Amirkhiz MB, Mirmahdavi S, Zabihi M. Levels of tetracycline residues in cattle meat, liver, and kidney from a slaughterhouse in Tabriz, Iran. Turkish J Vet Anim Sci. 2009;33:345-9.

22. Witte W. Selective pressure by antibiotic use in livestock. Int J Antimicrob Agents. 2000;16:19-24.

23. Scherer A, Vogt HR, Vilei EM, Frey J, Perreten V. Enhanced antibiotic multiresistance in nasal and faecal bacteria after agricultural use of streptomycin. Environ Microbiol. 2013;15:297-304

24. Farrag $\mathrm{H}$, El-Shatoury E, El-Baghdady K, Nada H. Prevalence of metallo- $\beta$ lactamase genes in multidrug resistant Gram negative bacilli. Egypt J Exp Biol. 2015;11:63-9.

25. Stagnitta PV, Micalizzi B, de Guzmán AMS. Prevalence of some bacteria yeasts and molds in meat foods in San Luis, Argentina. Cent Eur J Public Health. 2006;14:141-4.

26. Bae YY, Choi YM, Kim MJ, Kim KH, Kim BC, Rhee MS. Application of supercritical carbon dioxide for microorganism reductions in fresh pork. J Food Saf. 2011;31:511-7.

27. Gebeyehu A. Evaluation of microbial load of beef of Arsi cattle in Adama town, Oromia, Ethiopia. J Food Process Technol. 2013;04:1-7.

28. An KA, Jo Y, Arshad MS, Kim GR, Jo C, Kwon JH. Assessment of microbial and radioactive contaminations in Korean cold duck meats and electronbeam application for quality improvement. Korean J Food Sci Anim Resour. 2017;37:297-304.

29. Devriese LA, Pot B, Vandamme P, Kersters K, Collins MD, Alvarez N, et al. Streptococcus hyovaginalis sp. nov. and Streptococcus thoraltensis sp. nov., from the genital tract of sows. Int J Syst Bacteriol. 1997;47:1073-7.

30. Facklam R. What happened to the streptococci: overview of taxonomic and nomenclature changes. Clin Microbiol Rev. 2002:15:613-30

31. Moreno LZ, Matajira CEC, Gomes VTM, Silva APS, Mesquita RE, Christ APG, et al. Molecular and antimicrobial susceptibility profiling of atypical Streptococcus species from porcine clinical specimens. Infect Genet Evol. 2016;44:376-81. 
32. Alaidarous M, Alanazi M, Abdel-Hadi A. Isolation, identification, and antimicrobial susceptibility of bacteria associated with waterpipe contaminants in selected area of Saudi Arabia. Biomed Res Int. 2017;2017:1-7.

33. Vukonich M, Moline H, Chaussee M, Pepito B, Huntington MK. Case report: chorioamnionitis attributed to Streptococcus thoraltensis. S D Med. 2015;68:298-9.

34. Zhao S, Blickenstaff K, Bodeis-Jones S, Gaines SA, Tong E, McDermott PF. Comparison of the prevalences and antimicrobial resistances of Escherichia coli isolates from different retail meats in the United States, 2002 to 2008. Appl Environ Microbiol. 2012;78:1701-7.

35. Davis GS, Waits K, Nordstrom L, Grande H, Weaver B, Papp K, et al. Antibiotic-resistant Escherichia coli from retail poultry meat with different antibiotic use claims. BMC Microbiol. 2018;18:174.

36. Mirzaagha P, Louie M, Sharma R, Yanke LJ, Topp E, McAllister TA. Distribution and characterization of ampicillin- and tetracycline-resistant Escherichia coli from feedlot cattle fed subtherapeutic antimicrobials. BMC Microbiol. 2011;11:78.

37. Wang Y, Zhang S, Yu J, Zhang H, Yuan Z, Sun Y, et al. An outbreak of Proteus mirabilis food poisoning associated with eating stewed pork balls in brown sauce. Beijing Food Control. 2010;21:302-5.

38. Jiang $X, Y u T$, Liu L, Li Y, Zhang K, Wang H, et al. Examination of quaternary ammonium compound resistance in Proteus mirabilis isolated from cooked meat products in China. Front Microbiol. 2017:8:2417.

39. Barbour EK, Hajj ZG, Hamadeh S, Shaib HA, Farran MT, Araj G, et al. Comparison of phenotypic and virulence genes characteristics in human and chicken isolates of Proteus mirabilis. Pathog Glob Health. 2012;106:352-7.

40. Thayer DW, Boyd G. Effect of irradiation temperature on inactivation of Escherichia coli 0157:H7 and Staphylococcus aureus. J Food Prot. 2001;64:1624-6.

41. Van Gerwen SJC, Rombouts FM, Van't Riet K, Zwietering MH. A data analysis of the irradiation parameter $\mathrm{D} 10$ for bacteria and spores under various conditions. J Food Prot. 1999;62:1024-32.

42. Patterson M. Sensitivity of bacteria to irradiation on poultry meat under various atmospheres. Lett Appl Microbiol. 1988;7:55-8.

43. Clavero MR, Monk JD, Beuchat LR, Doyle MP, Brackett RE. Inactivation of Escherichia coli O157:H7, salmonellae, and Campylobacter jejuni in raw ground beef by gamma irradiation. Appl Environ Microbiol. 1994;60:2069-75.

44. Dion P, Charbonneau R, Thibault C. Effect of ionizing dose rate on the radioresistance of some food pathogenic bacteria. Can J Microbiol. 1994;40: 369-74

45. Yahia N, El May A, Helel S, Maatouk I, Saidi ACM, Landoulsi A. Gamma irradiation increases the sensitivity of Salmonella to antibiotics. Int J Sci Tech. 2015;4:279-88.

46. Shokier HA, Ei-Adly AA, Hussein H, Shabon MH, Ei-Shanshoury IH. Effect of gamma rays on antibiotic resistance of Staphylococcus aureus and Pseudomonas aeruginosa isolated from human skin. J Radiat Res Appl Sci. 2010;3(2):619-37.

47. Ben Abdallah F, Bakhrouf A, Ayed A, Kallel H. Alterations of outer membrane proteins and virulence genes expression in gamma-irradiated Vibrio parahaemolyticus and Vibrio alginolyticus. Foodborne Pathog Dis. 2009;6: $1171-6$.

48. Berrier C, Coulombe A, Houssin C, Ghazi A. Voltage-dependent cationic channel of Escherichia coli. J Membr Biol. 1993;133:119-27.

49. Josephson ES, Peterson MS. Preservation of food by ionizing radiation: volume II: CRC press; 1983.

50. Collins-Thompson DL, Wood DS, Thomson IQ. Detection of antibiotic residues in consumer milk supplies in North America using the charm test $\|$ procedure. J Food Prot. 1988;51:632-3.

51. Salter RS, Durbin GW, Bird P, Fisher K, Crowley E. Validation of the Peel plat $\mathrm{e}^{\mathrm{TM}} \mathrm{AC}$ for detection of total aerobic bacteria in dairy and nondairy products. J AOAC Int. 2016:99:143-52

52. CLSI. Performance Standards for Antimicrobial Susceptibility Testing. 27th ed. CLSI supplement M100. Wayne, PA: Clinical and Laboratory Standards Institute. USA; 2017. Wayne, PA, USA; 2017. www.clsi.org. Accessed 12 Mar 2020.

53. Sarker SD, Nahar L, Kumarasamy Y. Microtitre plate-based antibacterial assay incorporating resazurin as an indicator of cell growth, and its application in the in vitro antibacterial screening of phytochemicals. Methods. 2007:42:321-4.

54. Ingram, $\mathrm{M}$ and Roberts T. Effect of ionizing radiation on microorganisms. Acad Press New York. 1980;:1:191.

\section{Publisher's Note}

Springer Nature remains neutral with regard to jurisdictional claims in published maps and institutional affiliations.

\section{Ready to submit your research? Choose BMC and benefit from:}

- fast, convenient online submission

- thorough peer review by experienced researchers in your field

- rapid publication on acceptance

- support for research data, including large and complex data types

- gold Open Access which fosters wider collaboration and increased citations

- maximum visibility for your research: over $100 \mathrm{M}$ website views per year

At BMC, research is always in progress.

Learn more biomedcentral.com/submissions 